\title{
"Weekday effects on gold: Tokyo, London, and New York markets"
}

Hai-Chin Yu iD https://orcid.org/0000-0003-3274-4656

AUTHORS $\quad$ R https://publons.com/researcher/2441225/hai-chin-yu/

Chia-Ju Lee

Tung-Li Shih

Hai-Chin Yu, Chia-Ju Lee and Tung-Li Shih (2016). Weekday effects on gold:

ARTICLE INFO

Tokyo, London, and New York markets. Banks and Bank Systems, 11(2), 33-44. doi:10.21511/bbs.11(2).2016.04

DOI

http://dx.doi.org/10.21511/bbs.11(2).2016.04

RELEASED ON

Saturday, 02 July 2016

JOURNAL

"Banks and Bank Systems"

FOUNDER

LLC "Consulting Publishing Company "Business Perspectives"

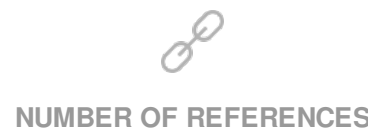

0

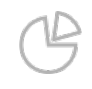

NUMBER OF FIGURES

0

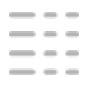

NUMBER OF TABLES

0

(C) The author(s) 2023. This publication is an open access article. 


\title{
Hai-Chin Yu (Taiwan), Lee Chia-Ju (Taiwan), Tung-Li Shih (Taiwan) Weekday effects on gold: Tokyo, London, and New York markets
}

\begin{abstract}
Using the probability distribution approach, this study explores the weekday effects among Tokyo, London, and New York gold markets. Friday shows positive and significant higher returns, whereas Tuesday shows negative and significant lower returns than other weekdays. The weekend effects still exist, while Monday effects disappear. On average, London was found to have the highest returns, followed by New York and Tokyo. The peak and width estimations show that Tokyo has the highest volatility, while London and New York have similar volatility distributions, implying a similar preference behavior of investors. It also implies that arbitrage opportunities between London and New York could be trivial. After estimating the distribution from Monday to Friday across the three markets, we found that the distribution of return shows a leftward shifting in London and New York, meaning that the weekend effect is starting earlier from Wednesday and Thursday in London and New York. Some strategy implications are valuable to traders or hedgers.
\end{abstract}

Keywords: gold, weekend effects, Monday effects, anomaly effects, calendar effects.

JEL Classification: C23, G10, G14, G15, F3.

\section{Introduction}

A vast amount of literature has documented that weekday returns vary with the day of the week across various types of assets and markets. Cross (1973), French (1980), and Gibbons and Hess (1981) found the traditional Monday effect in stock returns, in which the average returns on Monday are significantly negative and lower than the average returns on all other weekdays. Wingender and Groff (1989) concluded that the Monday effect is not due to outliers. Maberly (1995) pointed out that practitioners were aware of the Monday effect as early as the late 1920s. Aydoğan and Geoffrey (2003) investigated calendar anomalies in the Turkish foreign exchange market and found that free-market rates exhibit day-of-the-week and week-of-the-month effects. However, contrary to international evidence, Lauterbach and Meyer (1992) found that stock returns in Israel are higher the following weekends and holidays.

Although studies confirmed the Monday effect in equity returns, the existence of negative asset returns on Monday is still a puzzle. If this pattern has been known by the public, why do investors still buy securities on Friday and expect negative returns on the next trading day, Monday?

Academics have tried to explain the plausible reasons. Some suggest that this phenomenon may result from statistical errors (Gibbons and Hess, 1981; Chen, Lee and Wang, 2002). Sullivan, Timmermann and White (2001) argued that this calendar effect may result from data mining. Some researchers attributed the reasons to market efficiency, micro-market effect, or the set-

\footnotetext{
(C) Hai-Chin Yu, Lee Chia-Ju, Tung-Li Shih, 2016.

Hai-Chin Yu, Department of International Business, Chung Yuan University, Taiwan.

Lee Chia-Ju, College of Business, Chung Yuan University, Chungli, Taiwan, email: nancyli0208@hotmail.com.

Tung-Li Shih, Department of Hospitality Management, MingDao University, Changhua Peetow, Taiwan.
}

tlement procedure (Fama, 1991; Gibbons and Hess, 1981; Lakonishok and Levi, 1982; Dyl and Martin, 1985). In sum, while the Monday effect in equity returns has been widely documented, studies exploring the commodity markets are still lacking.

Some researchers found a shifting pattern in weekday returns for large-firm securities - Monday returns are no longer negative and significantly lower than other weekday returns. Small-firm securities, however, continue to maintain the same pattern of high returns on Friday and negative returns on Monday. Arsad and Coutts (1996) found that, although the weekend effect existed in the Financial Times Industrial Ordinary Shares Index (FT 30 index) of London from 1935 to 1994, it did not exist in the 12 five-year sub-periods. They also found strong evidence of the weekend effect in a bad-news environment instead of a good-news environment. Coutts (1999) found no evidence of a Friday-the-13th effect on the FT 30 index. On the contrary, returns are higher on Friday the 13th than on any other Friday. Kallunki and Martikaninen (1997) found that the average daily returns from Monday to Wednesday are 0.15 percentage points lower than the rest of the week in Finland, meaning the weekday effect exists in Finland.

The weekday effect is also observed in other types of debt - and equity-related securities (Gibbons and Hess, 1981; Flannery and Protopapadakis, 1988; Griffiths and Winters, 1995; Johnston, Kracaw, and McConnell, 1991; Jordan and Jordan, 1991; Ma and Goebel, 1991; Singleton and Wingender, 1994). In addition, the weekday effect exists in non-equity and non-debt markets. Ball, Torous and Tschoegl (1982) and Ma (1986) found the weekday effect in the gold market. However, Coutts and Sheikh (2000) found no January effect or calendar effect in the All Gold Index on the Johannesburg Stock Exchange over the sample period. Coats (1981), McFarland, Pettit and Sung (1982), Thatcher and Blenman (2001), and 
$\mathrm{Yu}$, Chiou and James (2008) found weekday effects in yen/dollar foreign exchange market. This effect has been variously attributed to settlement issues, asymmetries in bid-ask spreads, and measurement errors. Redman, Manakyan and Llano (1997) found the weekday effect in real-estate investment trusts. Overall, the weekday effect seems to occur in a wide spectrum of asset markets.

This paper investigates whether the weekday effect exists in gold markets across Tokyo, London, and New York. Our paper differs from previous papers in a few important aspects. First, we use probability distribution to analyze the potential calendar anomaly in gold, which was not done by the prior papers. Second, we fit the return distributions from Monday to Friday across three gold markets and estimate the distribution parameters. This approach can avoid potential biases resulting from observing only mean returns and neglecting the entire overlook of the distribution. Third, we fit the volatility distributions from Monday to Friday in the three gold markets and calculate the distribution parameters, such as height and width. These estimates can help to explore the micro-behavior of weekday returns. It is also interesting to know whether the time horizon is a key factor in changing the weekday return pattern.

The rest of this paper is organized as follows. Section 1 briefly discusses data and methodology. In section 2 , we estimate the probability distributions of intraday return volatility and the intraday returns of gold price. In section 3, the panel probability distributions from Monday to Friday in Tokyo, London, and New York are reported and discussed. We summarize and conclude in final section.

\section{Data description and intraday returns}

We obtained daily gold spot prices of the Tokyo, London, and New York markets from DataStream over December 29, 1978 - December 16, 2011. Because holidays in Japan, U.K., and the U.S. differ, we, first, aligned the spot prices contracts by date and deleted the dates on which, at least, one market did not trade in order to align the data set. Then, we calculated the returns for each day.
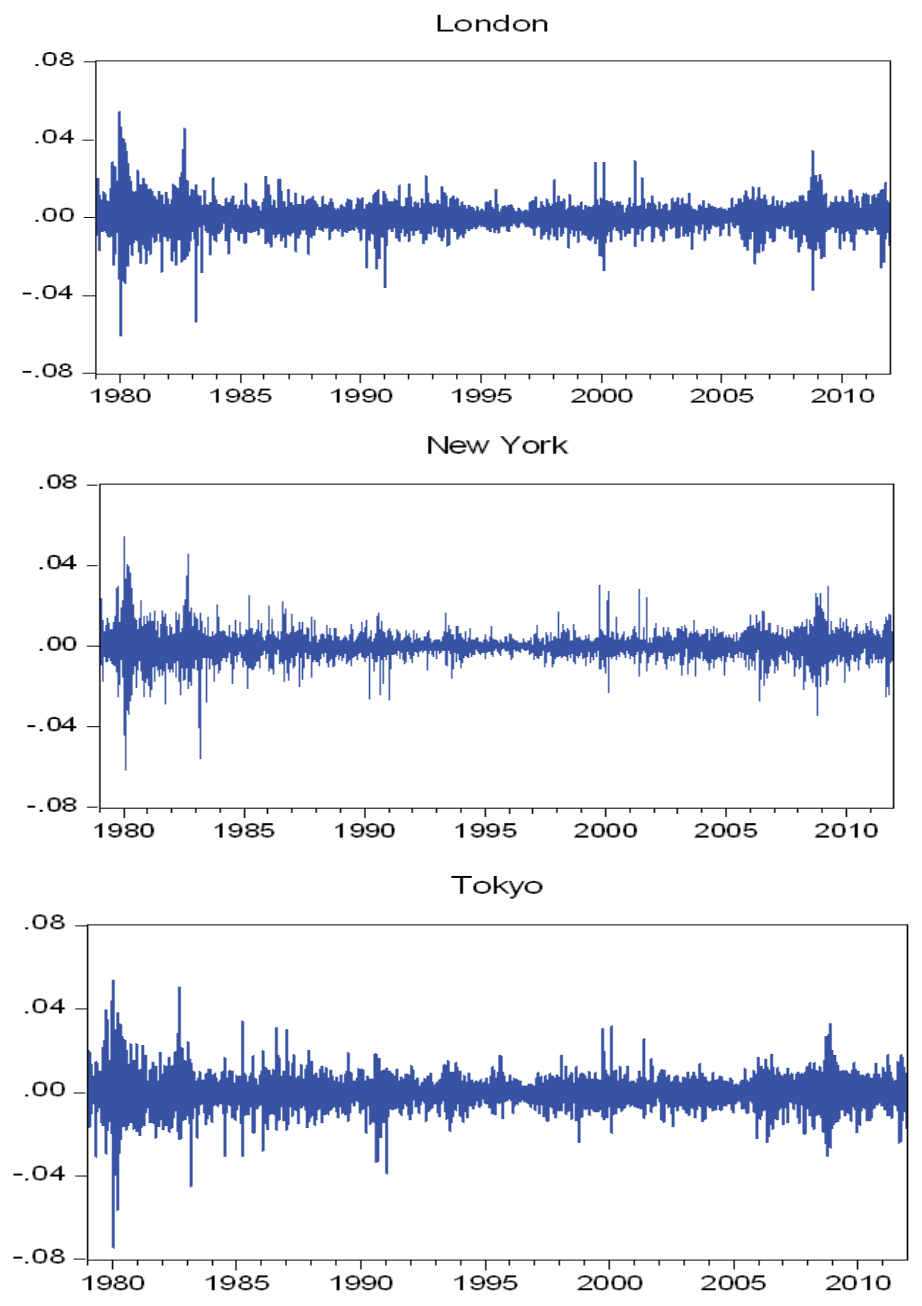

Fig. 1. Time series of daily returns for gold in London, Tokyo and New York (The sample period is from December 29, 1978 to December 16, 2011) 
Figure 1 shows the time series of daily gold returns for the Tokyo, London, and New York gold markets from December 29, 1978 to December 16, 2011. The return behaviors of these three time series seem remarkably similar. Overall, there seems to be a high degree of integration between the three gold markets, although they are located in three different continents with different time zones.

Table 1. Summary statistics of intraday gold returns in Tokyo, London and New York

\begin{tabular}{|l|c|c|c|}
\hline \multicolumn{1}{|c|}{ Spot } & Tokyo & London & New York \\
\hline Mean & 0.00005 & 0.00011 & 0.00010 \\
\hline Median & 0.00001 & 0.00000 & 0.00000 \\
\hline Maximum & 0.05364 & 0.05431 & 0.05429 \\
\hline Minimum & -0.07428 & -0.06059 & -0.06166 \\
\hline Standard deviation & 0.00586 & 0.00535 & 0.00539 \\
\hline Skewness & -0.08785 & 0.11409 & 0.07100 \\
\hline Kurtosis & 15.18862 & 14.84264 & 15.47516 \\
\hline
\end{tabular}

Table 1 presents summary statistics of the intraday gold returns in the three markets. London has positive and the highest returns $(0.00011)$, while Tokyo has the lowest ones (0.00005). Interestingly, standard deviations of the intraday returns in the three markets are close to each other ( 0.005). The return distribution of Tokyo is left-skewed (negative skewness) and more peaked (the highest kurtosis) than London's and New York's.

\section{Model specification}

2.1. Probability distributions of intraday returns. Let us first introduce the notations. The gold return is expressed by $R_{i}(t)$, and the time series of daily returns, $R_{i}(t)$ is defined as the change in the logarithm of the daily price as expressed in equation (1):
$R_{i}(t)=\ln Z_{i}\left(t+\delta_{t}\right)-\ln Z_{i}(t)$,

where $\delta_{t}$ denotes the time interval of the sampling with $\delta_{t}=1$ day. We further define the define the probability distribution, $P$, as a normalized distribution of the daily returns, $R(t)$, which satisfies

$$
\int_{-\infty}^{\infty} P(R) d R=1 \text {. }
$$

The probability distributions of gold returns, $P(R)$, in the London, New York, and Tokyo are shown in Figure 2. These distributions are shown with variant kurtosis.

Table 2. Summary statistics of intraday gold volatility in Tokyo, London, and New York

\begin{tabular}{|l|c|c|c|}
\hline \multicolumn{1}{|c|}{ Spot } & Tokyo & London & New York \\
\hline Mean & 0.00623 & 0.005706 & 0.005704 \\
\hline Median & 0.005377 & 0.00496 & 0.004843 \\
\hline Maximum & 0.079201 & 0.065067 & 0.066179 \\
\hline Minimum & 0.0000 & 0.0000 & 0.0000 \\
\hline Standard deviation & 0.004882 & 0.004389 & 0.004446 \\
\hline Skewness & 2.591206 & 2.656276 & 2.774347 \\
\hline Kurtosis & 19.49195 & 19.13521 & 19.80869 \\
\hline
\end{tabular}

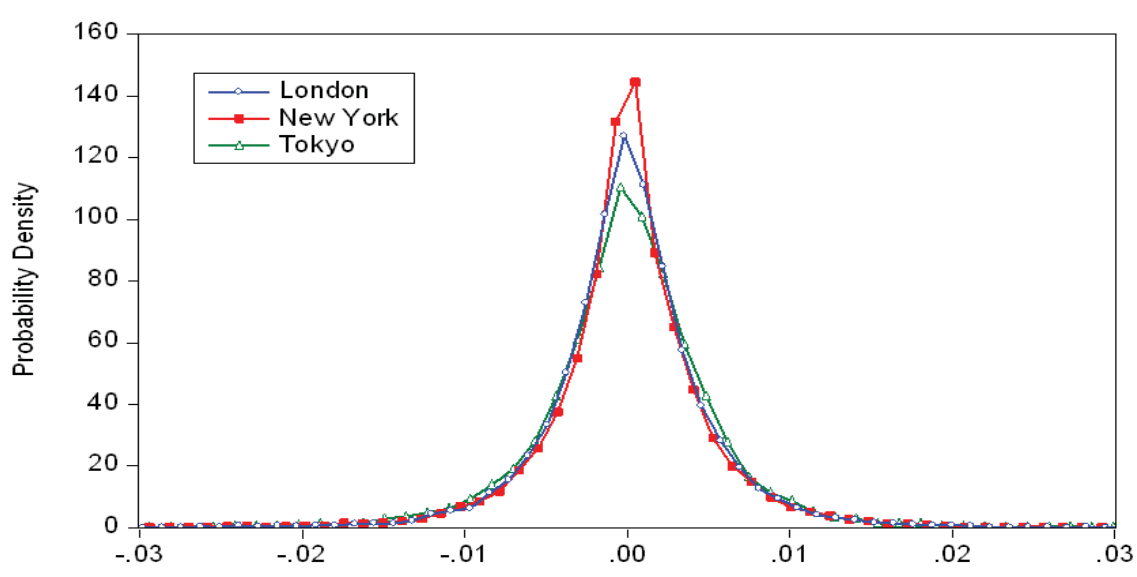

Fig. 2. Probability distributions of gold returns in London 
2.2. Probability distributions of intraday return volatility. In this section, we construct the probability distributions of gold return volatility across Tokyo, London and New York.

First, we used the histogram method to count the value of volatility $N\left(V_{n}\right)$ ranging between $V_{n}=n$ $(\Delta V)$ and $V_{n}+1=(n+1)(\Delta V)$, with $\Delta V=0.0005$. Here, $\mathrm{n}$ is an integer ranging between 0 and $\infty$. The probability of volatility in the interval between $V_{n}$ and $V_{n}+1$ is, then, given as

$$
P\left(V_{n}\right), \Delta V=\frac{N\left(V_{n}\right)}{\sum_{m=0}^{\infty} N\left(V_{m}\right)} \text {. }
$$

with the normalization:

$\sum_{n=0}^{\infty} P\left(V_{n}\right), \Delta V=1$.

As can be observed in Figure 3, at least two characteristics are worth mentioning. First, each distribution is asymmetric with a peak. Second, each distribution has a longer tail than the Gaussian distribution. Yu and Huang (2004) suggested that a lognormal function can take both characteristics into account when calculating the volatility distribution. Following their methodology, we employed the following form of the distribution function:

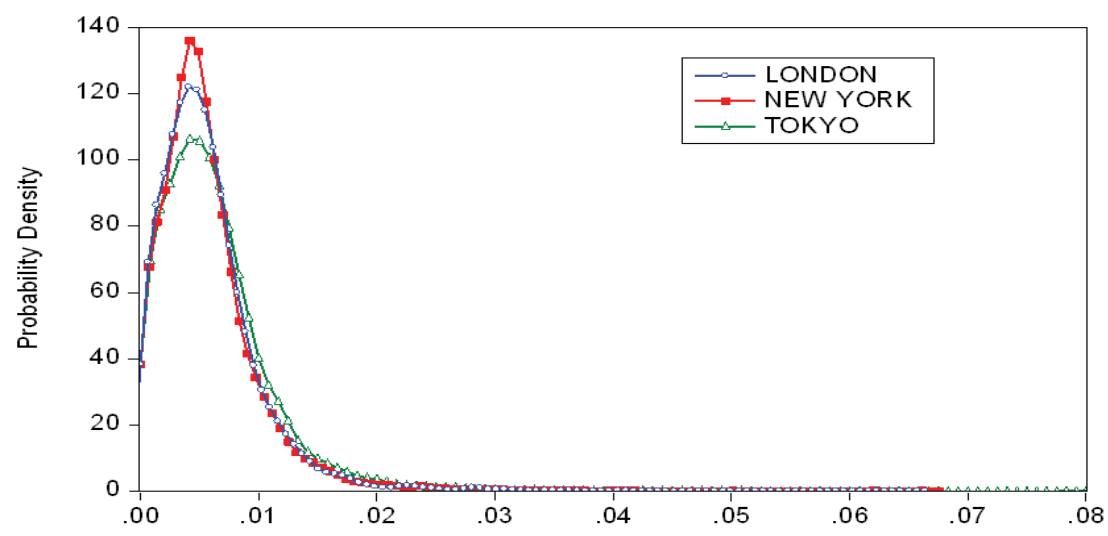

Fig. 3. Probability distributions of gold volatility in London, New York and Tokyo

$$
P(V)=\frac{1}{V w \sqrt{2 \pi}} \exp \left[-\frac{1}{2 w^{2}}\left(\ln \frac{V}{V_{c}}\right)^{2}\right]
$$

We estimate $V_{c}$ and $w$ first and, then, calculate the corresponding log-normal parameters $\mu$ and $\sigma$ by calculating and:

$$
\sigma=\sqrt{\exp \left(2 \ln V_{c}+w^{2}\right)\left(\exp \left(w^{2}\right)-1\right)} \text {. }
$$

This function contains two adjustable parameters, $V_{c}$ and $\mathrm{w}$, indicating the peak probability location and the distribution width, respectively.

This distribution function is normalized as follows:

$$
\int_{0}^{\infty} P(V) d V=1
$$

The three fitting curves of the log-normal distribution functions are represented by the dotted lines in Figure 3. The corresponding values of the two parameters $V_{c}$ and $\mathrm{w}$ are reported in Table 4, which also presents the highest volatility probability $V_{\mathrm{c}}$; the width of the peak, w; the average volatility, $V(t)$, indicating global vola- tility; and the standard deviation of the volatility, indicating fluctuations in volatility.

2.3. Probability Distributions from Monday to Friday in Tokyo, London, and New York. On the basis of probability distribution, this section explores differences, if any, in gold returns and volatility between Tokyo, London and New York.

2.4. Descriptive statistics of gold returns from Monday to Friday. Table 3 shows that London has the highest returns $(0.000385)$ on Friday, followed by New York (0.00029) and Tokyo (0.000215). This result implies that a weekend effect exists in gold markets. Tuesday exhibits negative and the lowest returns, while Wednesday shows positive returns in three markets. Monday exhibits negative and the lowest returns in New York (-0.000008), and Thursday shows negative returns in Tokyo (-0.000209). Hence, there was no evidence of Monday effects in gold markets. Investors who buy gold is guided by different markets. Our Scheffe's test indicated a significant difference between Tokyo and London and between Tokyo and New York, but not between London and New York from Monday to Friday. 
Table 3. Summary statistics of panel intraday returns from Monday to Friday in Tokyo, London and New York

\begin{tabular}{|c|c|c|c|c|c|}
\hline & Mean & $\begin{array}{l}\text { Standard } \\
\text { deviation }\end{array}$ & Skewness & Kurtosis & Jarque-Bera \\
\hline \multicolumn{6}{|l|}{ Monday returns } \\
\hline Tokyo & 0.000089 & 0.006542 & -0.17315 & 8.238424 & 1748.976 \\
\hline London & 0.000059 & 0.006204 & -0.40592 & 11.0094 & 4112.71 \\
\hline New York & -0.000008 & 0.006124 & -0.63015 & 12.20163 & 5473.805 \\
\hline Scheffe's test & \multicolumn{5}{|c|}{ Tokyo vs. London (0.0385); Tokyo vs. New York (0.010); London vs. New York (0.6133) } \\
\hline \multicolumn{6}{|c|}{ Tuesday returns } \\
\hline Tokyo & -0.000209 & 0.006005 & -0.02574 & 9.58591 & 2752.623 \\
\hline London & -0.000036 & 0.005533 & -0.57343 & 16.22509 & 11182.53 \\
\hline New York & -0.000056 & 0.005658 & -0.58129 & 16.39139 & 11465.71 \\
\hline Scheffe's test & \multicolumn{5}{|c|}{ Tokyo vs. London (0.0014); Tokyo vs. New York (0.0204); London vs. New York (0.382) } \\
\hline \multicolumn{6}{|c|}{ Wednesday returns } \\
\hline Tokyo & 0.000165 & 0.006343 & -0.57421 & 20.19729 & 18851.3 \\
\hline London & 0.000162 & 0.005604 & 0.454701 & 11.74586 & 4906.418 \\
\hline New York & 0.000275 & 0.00578 & 0.519314 & 11.62363 & 4787.665 \\
\hline Scheffe's test & \multicolumn{5}{|c|}{ Tokyo vs. London (0.000); Tokyo vs. New York (0.0003); London vs. New York (0.2264) } \\
\hline \multicolumn{6}{|c|}{ Thursday returns } \\
\hline Tokyo & -0.000007 & 0.006038 & 0.365575 & 13.42293 & 6927.876 \\
\hline London & 0.0000278 & 0.005392 & 0.492178 & 14.61773 & 8626.562 \\
\hline New York & 0.0000198 & 0.005461 & 0.630376 & 14.61036 & 8655.075 \\
\hline Scheffe's test & \multicolumn{5}{|c|}{ Tokyo vs. London (0.00); Tokyo vs. New York (0.0001); London vs. New York (0.6213) } \\
\hline \multicolumn{6}{|c|}{ Friday returns } \\
\hline Tokyo & 0.000215 & 0.006197 & 0.077142 & 15.82785 & 10443.81 \\
\hline London & 0.000385 & 0.005661 & 0.722233 & 12.77916 & 6201.045 \\
\hline New York & 0.00029 & 0.005606 & 0.613152 & 13.97316 & 7736.464 \\
\hline Scheffe's test & \multicolumn{5}{|c|}{ Tokyo vs. London (0.0001); Tokyo vs. New York (0.0004); London vs. New York (0.7007) } \\
\hline
\end{tabular}

2.5. Results of estimated parameters of the return distribution. Figures 4 (a) and 4 (b) show average returns, two- and three-dimensionally, respectively, on weekdays in Tokyo, London and New York. The highest and lowest returns appear on Friday and Tuesday, respectively, which shows the evidence of the weekend effect and Tuesday effect.

To sum up, the traditional weekend effect has been lengthened in the gold market. Specifically, the Friday effect still exist, and Monday effect has been replaced by the Tuesday effect. In other words, to earn excess returns, it is likely that investors buy gold on Friday and hold it until the next Tuesday.
We interpret this from the perspective of a rational market: if investors know that the returns on gold is better on Friday than on other days, they will buy gold on Thursday and shift the positive returns earlier. Similarly, if investors know that the gold price is likely to be marked down on Monday, they are likely to avoid having their own gold marked down on Monday, so that they can sell it late on Tuesday. Given that gold has the unique characteristic of value preservation, a long-term holding period is better and, hence, the negative returns were rightward-shifting to the next day, Tuesday.

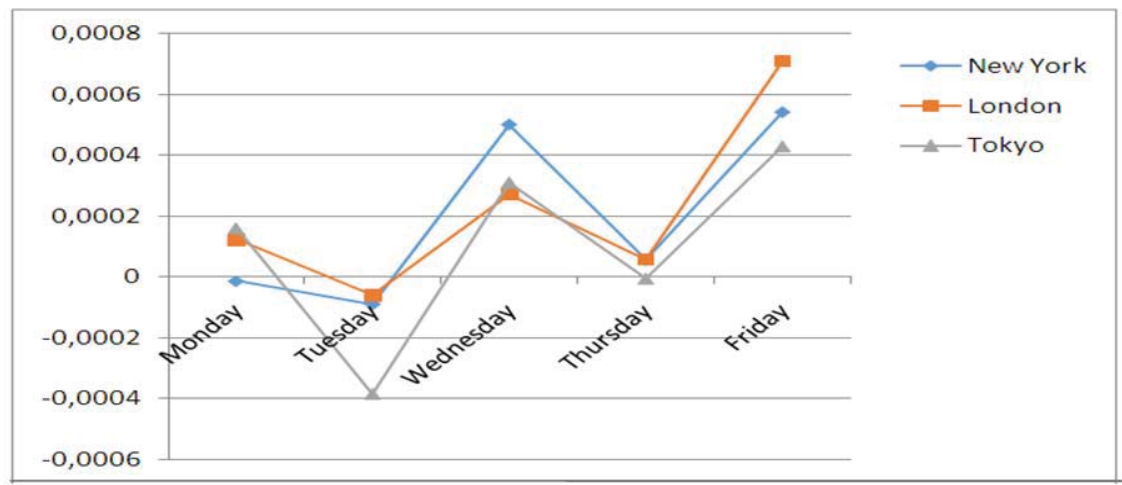

(a) 


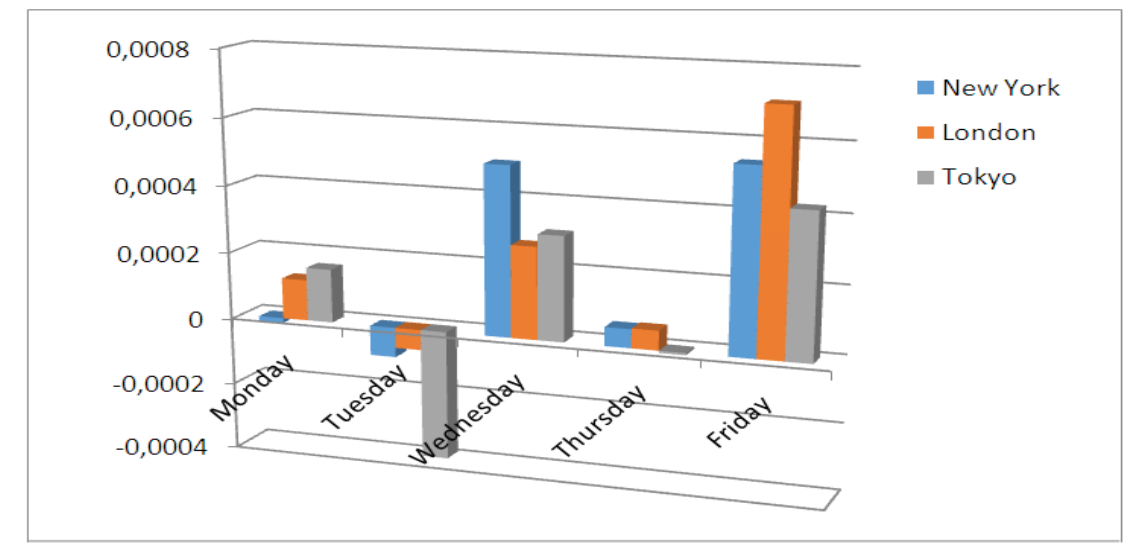

Fig. 4(a). Two-dimensional and (b) three-dimensional weekday returns from Monday to Friday in New York, London and Tokyo

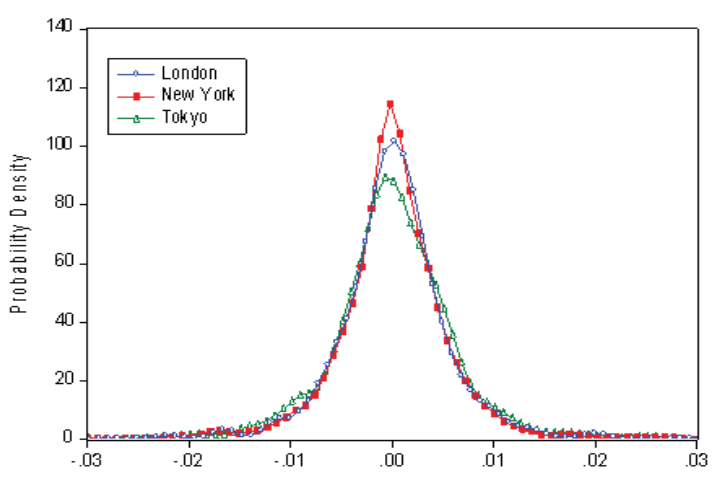

(a) Monday

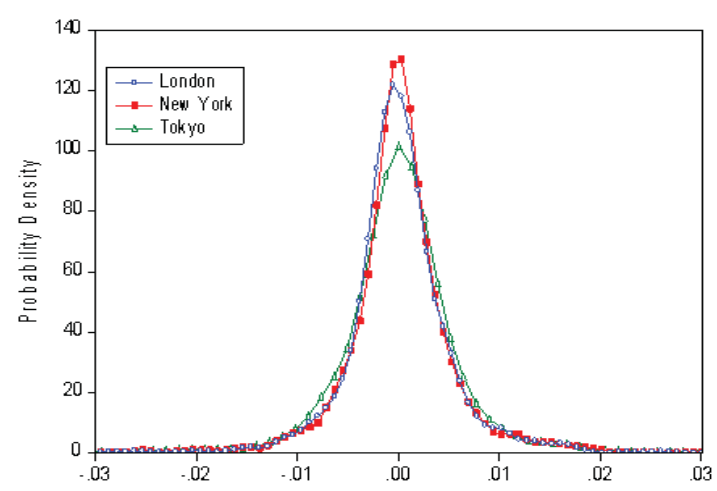

(c) Wednesday

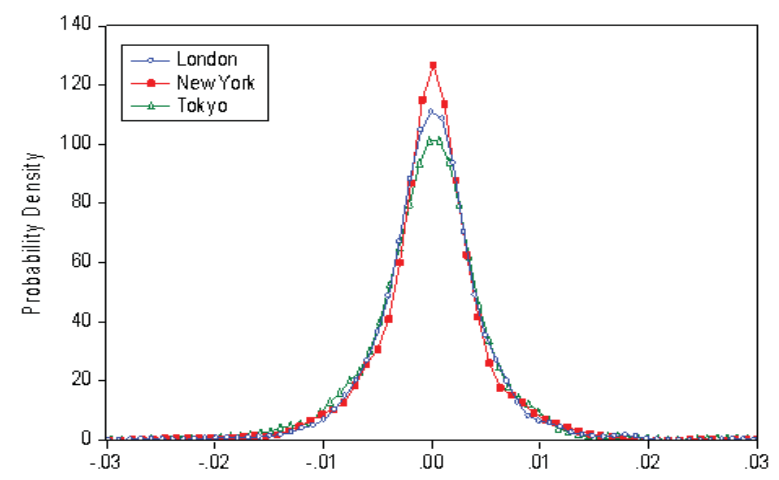

(b) Tuesday

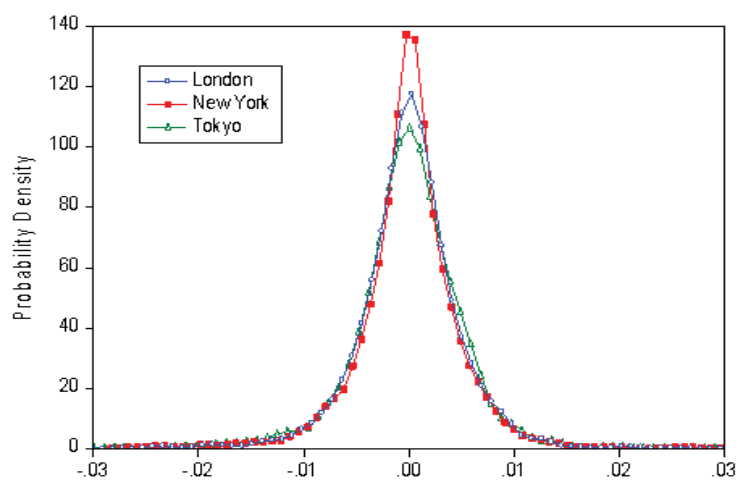

(d) Thursday

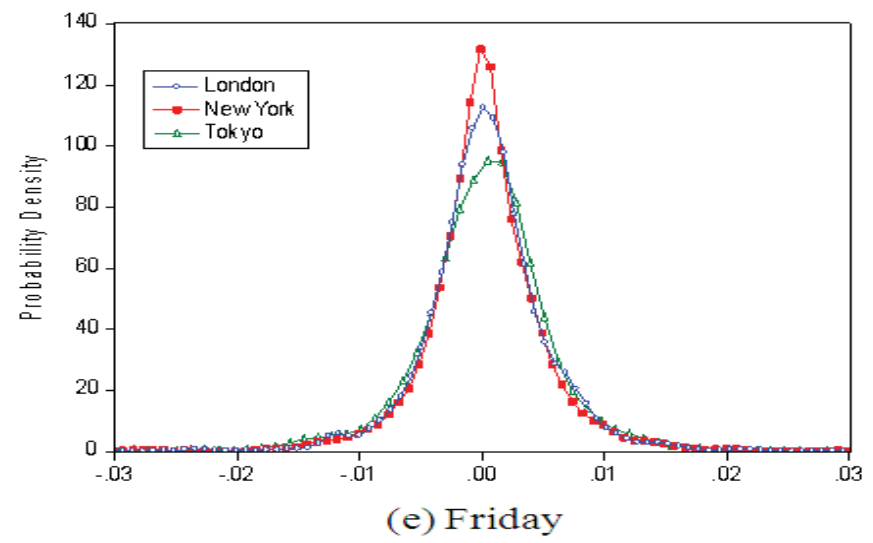

Fig. 5. Probability distributions of gold returns from Monday to Friday in London, New York, and Tokyo 
Figure 5 (a-e) shows the probability distributions of returns from Monday to Friday in Tokyo, London, and New York. Not surprisingly, Thursday has the highest return peaks associated with an average width for New York and Tokyo, while Wednesday has the highest return peak for London. This implies that Thursday and Wednesday may have the highest probability of earning abnormal returns. These distributions imply that investors already implement the buying strategy in advance, that being said earlier than Friday and make average returns on Friday the highest. Due to the highest returns in London. To check the consistency, the authors, therefore, fitted a Gaussian function to measure the distribution parameters. The estimated coefficients in Table 4 show that Tokyo and New York have the greatest peaks of 78.209 and 77.232, respectively, on Thursday, while London has the greatest peak, 70.193, on Tuesday. The widest width, $0.65(0.0062,0.0061)$, appears on Monday for all three markets.

Table 4. Parameter estimates of weekday returns of the Gaussian function of Tokyo, London and New York

\begin{tabular}{|c|c|c|c|}
\hline & Center (R0) & Width (w) & Height $(\mathrm{Vc})$ \\
\hline \multicolumn{4}{|c|}{ Monday returns } \\
\hline Tokyo & 0.0000691 & 0.006504 & 64.593 \\
\hline London & 0.0000663 & 0.006169 & 61.294 \\
\hline New York & 0.0000675 & 0.006124 & 65.058 \\
\hline \multicolumn{4}{|c|}{ Tuesday returns } \\
\hline Tokyo & -0.00019 & 0.005678 & 76.105 \\
\hline London & 0.000031 & 0.005231 & 70.193 \\
\hline New York & -0.0000453 & 0.005350 & 74.425 \\
\hline \multicolumn{4}{|c|}{ Wednesday returns } \\
\hline Tokyo & 0.000159 & 0.005988 & 75.315 \\
\hline London & 0.000134 & 0.005291 & 66.466 \\
\hline New York & 0.000252 & 0.005457 & 73.026 \\
\hline \multicolumn{4}{|c|}{ Thursday returns } \\
\hline Tokyo & -0.0000326 & 0.005702 & 78.209 \\
\hline London & 0.0000293 & 0.005092 & 69.875 \\
\hline New York & 0.0000281 & 0.005157 & 77.232 \\
\hline \multicolumn{4}{|c|}{ Friday returns } \\
\hline Tokyo & 0.000233 & 0.005904 & 73.877 \\
\hline London & 0.000371 & 0.005394 & 67.474 \\
\hline New York & 0.000272 & 0.005341 & 74.610 \\
\hline
\end{tabular}

Our findings confirm that investors still follow the similar behaviors or beliefs prefer to buy gold on weekend over these decades. This finding is consistent to those of Ball et al. (1982), Ma (1986), and Kompa and Matuszewska (2007), who demonstrated that the weekend effect exists in the gold market. However, the holding period is lengthened to the next Tuesday.

One possible reason could be internet trading with its low cost may enhance the investors' trading behavior, increasing the expected excess returns over weekends. Among the three markets, the following strategy can make traditional weekend effects more profitable: investors buy gold earlier or on Friday in London and sell it lately on Tuesday in Tokyo. We interpret this finding using the same perspective of a rational market as for gold: If investors know that excess returns on gold may appear on Friday, they will buy gold on Thursday and shift the positive returns earlier to other days. Similarly, when Monday is expected to result in negative returns in Tokyo and London, investors are likely to postpone to mark down the gold price on Tuesday on the basis of volatility. All these beliefs shift the distributions of the traditional weekend effects leftward and Monday effects rightward. Besides, this behavior may also imply information flows reflecting the investors' behavior that is gradually changing from being on a day-to-day basis.

Another possible reason is the announcement effect: The American Petroleum Institute regularly announces the crude oil price on Tuesday, which discounts the crude oil price on Wednesday. Due to gold and oil is highly correlated, this may indirectly influence the gold distribution leftwardshifting. Our findings complement those of Singleton anWingender (2003) from a news release perspective and add an extra dimension in the form of a probability distribution to explain the leftwardshifting weekday effect of gold.

2.6. Results of estimated parameters of the volatility distribution. In Table 5, we compute the return volatility, standard deviation, skewness, kurtosis, and Jarque-Bera (J-B) value of gold in the Tokyo, London, and New York markets. The volatility distribution of gold is slightly right- 
skewed (skewness >0) and leptokurtic (kurtosis > 3). However, the skewness and kurtosis for London and New York are significantly larger than those in Tokyo on Monday, Tuesday, and Thursday, imply- ing that London and New York have a much higher risk than Tokyo on Monday, Tuesday, and Thursday. On Wednesday and Friday, Tokyo has a much higher risk than London and New York.

Table 5. Summary statistics of panel intraday volatility Monday to Friday in Tokyo, London and New York

\begin{tabular}{|c|c|c|c|c|c|}
\hline & Mean & $\begin{array}{l}\text { Standard } \\
\text { deviation }\end{array}$ & Skewness & Kurtosis & Jarque-Bera \\
\hline \multicolumn{6}{|c|}{ Monday volatility } \\
\hline Tokyo & 0.007477 & 0.005273 & 1.825697 & 10.40109 & 4322.071 \\
\hline London & 0.007066 & 0.005037 & 2.347417 & 15.53846 & 11375.2 \\
\hline New York & 0.007033 & 0.005062 & 2.498107 & 17.38357 & 14712.76 \\
\hline \multicolumn{6}{|c|}{ Tuesday volatility } \\
\hline Tokyo & 0.006009 & 0.004609 & 2.143914 & 12.86877 & 8220.24 \\
\hline London & 0.005466 & 0.004219 & 3.140124 & 30.50451 & 56511.71 \\
\hline New York & 0.005549 & 0.004323 & 3.243722 & 30.23025 & 55633.7 \\
\hline \multicolumn{6}{|c|}{ Wednesday volatility } \\
\hline Tokyo & 0.005957 & 0.004802 & 3.67327 & 39.74191 & 99972.18 \\
\hline London & 0.005441 & 0.004113 & 2.592567 & 16.43769 & 14772.68 \\
\hline New York & 0.005453 & 0.004227 & 2.640064 & 15.99068 & 14002.23 \\
\hline \multicolumn{6}{|c|}{ Thursday volatility } \\
\hline Tokyo & 0.00586 & 0.004726 & 2.547679 & 15.46454 & 12904.47 \\
\hline London & 0.005197 & 0.00412 & 2.726513 & 19.22866 & 20859.3 \\
\hline New York & 0.005176 & 0.004174 & 2.773714 & 18.04795 & 18305.11 \\
\hline \multicolumn{6}{|c|}{ Friday volatility } \\
\hline Tokyo & 0.005975 & 0.004849 & 2.922616 & 22.25306 & 28305.56 \\
\hline London & 0.005504 & 0.004224 & 2.55648 & 16.03835 & 13713.52 \\
\hline New York & 0.005447 & 0.004229 & 2.79505 & 17.93747 & 17785.21 \\
\hline
\end{tabular}

Table 6. Estimated coefficients of the volatility of the log-normal function in Tokyo, London and New York

\begin{tabular}{|c|c|c|c|c|c|}
\hline & Mean & $\begin{array}{l}\text { Standard } \\
\text { deviation }\end{array}$ & Peak & Width & Volatility area \\
\hline \multicolumn{6}{|c|}{ Monday volatility } \\
\hline Tokyo & 0.007477 & 0.005273 & 0.007477 & 0.005273 & $0.002204-0.01275$ \\
\hline London & 0.007066 & 0.005037 & 0.005466 & 0.004219 & $0.001247-0.009685$ \\
\hline New York & 0.007033 & 0.005062 & 0.007033 & 0.005062 & $0.001971-0.012095$ \\
\hline \multicolumn{6}{|c|}{ Tuesday volatility } \\
\hline Tokyo & 0.006009 & 0.004609 & 0.006009 & 0.004609 & $0.0014-0.010618$ \\
\hline London & 0.005466 & 0.004219 & 0.005466 & 0.004219 & $0.001247-0.009685$ \\
\hline New York & 0.005549 & 0.004323 & 0.005549 & 0.004323 & $0.001226-0.009872$ \\
\hline \multicolumn{6}{|c|}{ Wednesday volatility } \\
\hline Tokyo & 0.005957 & 0.004802 & 0.005957 & 0.004802 & $0.001155-0.010759$ \\
\hline London & 0.005441 & 0.004113 & 0.005441 & 0.004113 & $0.001328-0.009554$ \\
\hline New York & 0.005453 & 0.004227 & 0.005453 & 0.004227 & $0.001226-0.00968$ \\
\hline \multicolumn{6}{|c|}{ Thursday volatility } \\
\hline Tokyo & 0.00586 & 0.004726 & 0.00586 & 0.004726 & $0.001134-0.010586$ \\
\hline London & 0.005197 & 0.00412 & 0.005197 & 0.00412 & $0.001077-0.009317$ \\
\hline New York & 0.005176 & 0.004174 & 0.005176 & 0.004174 & $0.001002-0.00935$ \\
\hline \multicolumn{6}{|c|}{ Friday volatility } \\
\hline Tokyo & 0.005975 & 0.004849 & 0.005975 & 0.004849 & $0.001126-0.010824$ \\
\hline London & 0.005504 & 0.004224 & 0.005504 & 0.004224 & $0.00128-0.009728$ \\
\hline New York & 0.005447 & 0.004229 & 0.005447 & 0.004229 & $0.001218-0.009676$ \\
\hline
\end{tabular}

To better understand volatility, we estimated the peak and width parameters of the volatility function. Table 6 shows that Monday has the highest peak of 0.0075 associated with a width of 0.0053 in Tokyo. Results suggest that the biggest discrepancy in terms of investors' beliefs occurs in the beginning of the week.
Thursday shows the lowest peak of 0.0057 (0.005197, $0.005176)$ in all three cities. Given that the peak and width range $(\mathrm{Vc} \pm \mathrm{w})$ represents the volatility area, the London market is obviously more volatile than the Tokyo and New York markets and has a larger discrepancy in terms of investors' beliefs. 


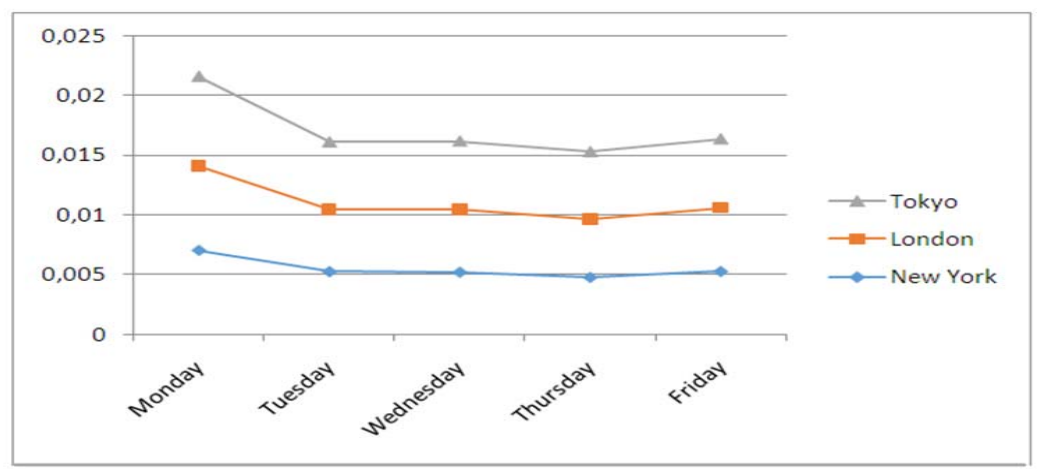

(a)

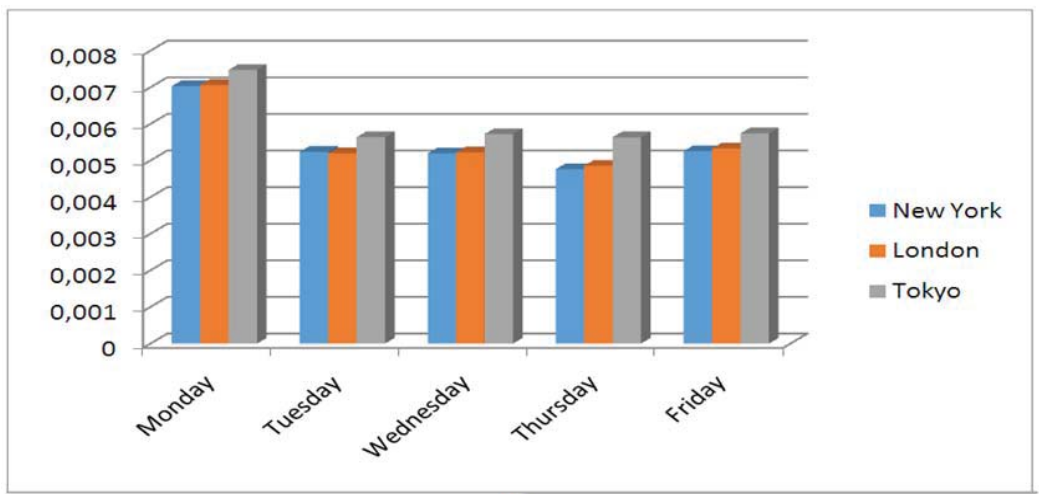

(b)

Fig. 6(a) Two-dimensional and (b) three-dimensional weekday volatility from Monday to Friday in Tokyo, London, and New York

Figure 6(a) shows the volatility of intraday returns on a two-dimensional graph from Monday to Friday in Tokyo, London, and New York. The volatility decreases from Monday to Thursday and then slightly increases in Friday. Mondays show the highest volatility in three markets.

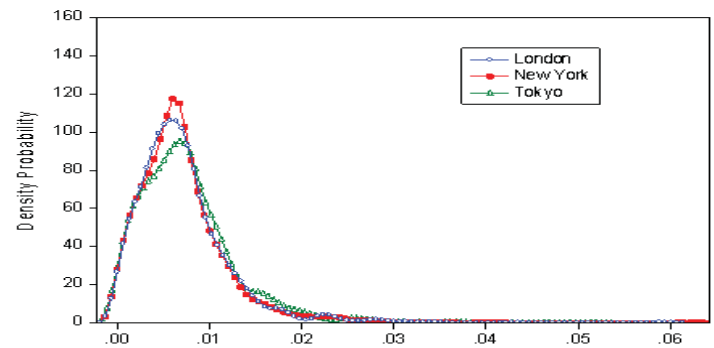

(a) Monday

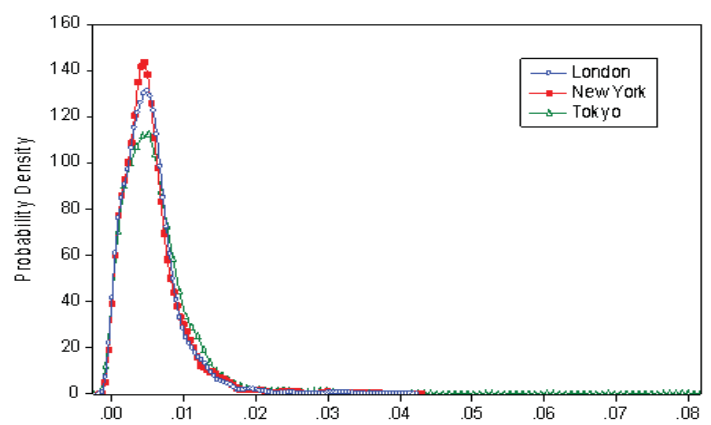

(c) Wednesday
Figure 6(b) shows the volatility of returns on a three-dimensional graph. Generally, the volatility patterns across the three markets are similar on weekdays. Monday shows the highest volatility across the three markets, with Tokyo exhibiting the highest volatility.

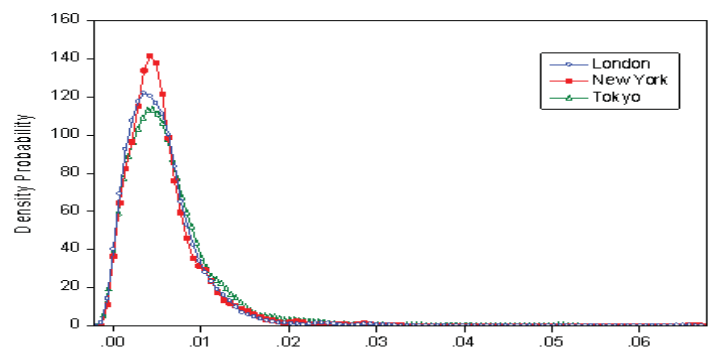

(b) Tuesday

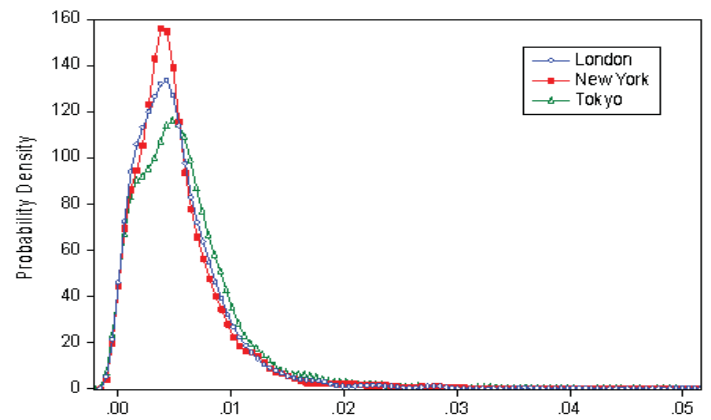

(d) Thursday 


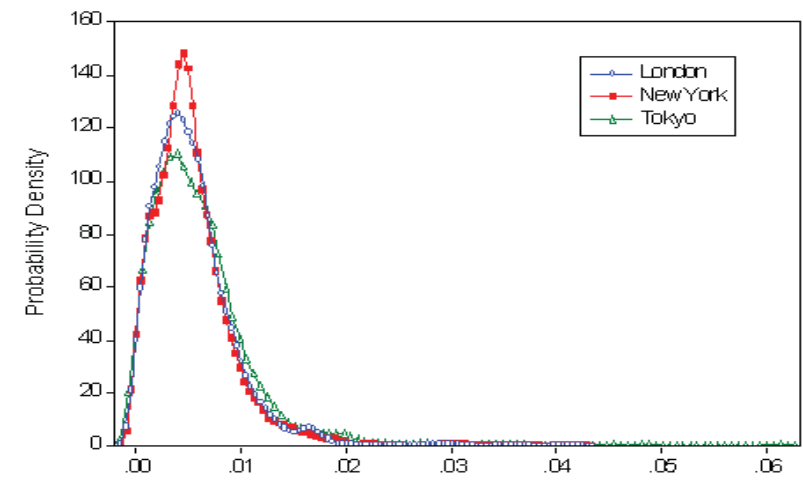

(e) Friday

Fig. 7. Probability distributions of gold volatility from Monday to Friday in London, New York and Tokyo

The volatility distribution are displayed in Figure 7 (a-e). London has the lowest volatility, with a distribution associated with the highest peak and a narrower width than Tokyo and New York from Monday to Friday. Moreover, Thursday has the highest volatility. This phenomenon is similar across the three markets. We can also see that volatility is lowest on Monday. All this information about the distribution parameters reveals more consistent evidence of the three gold markets.

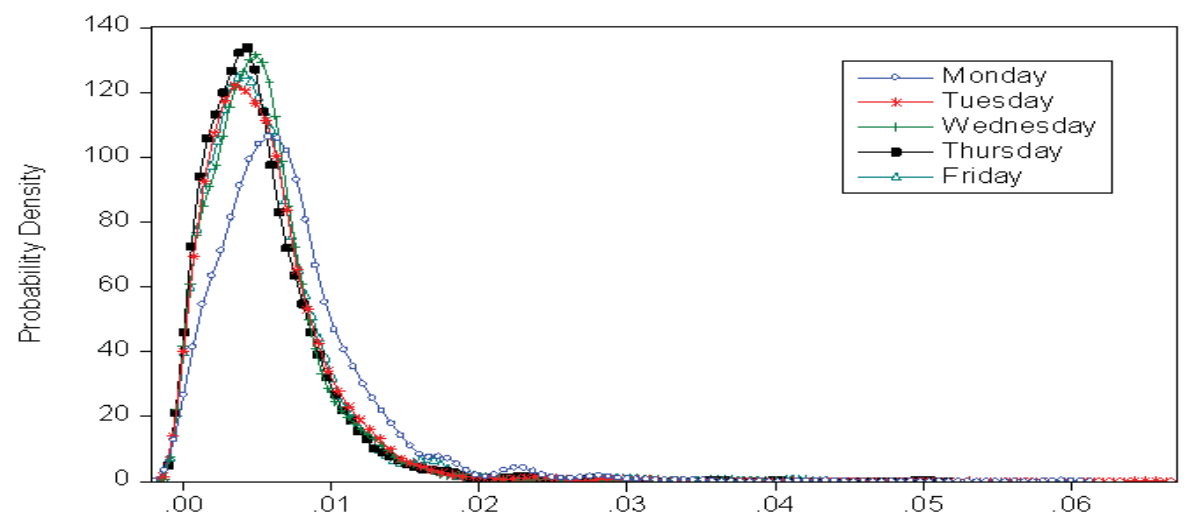

Fig. 8. Probability distributions of gold volatility from Monday to Friday in London

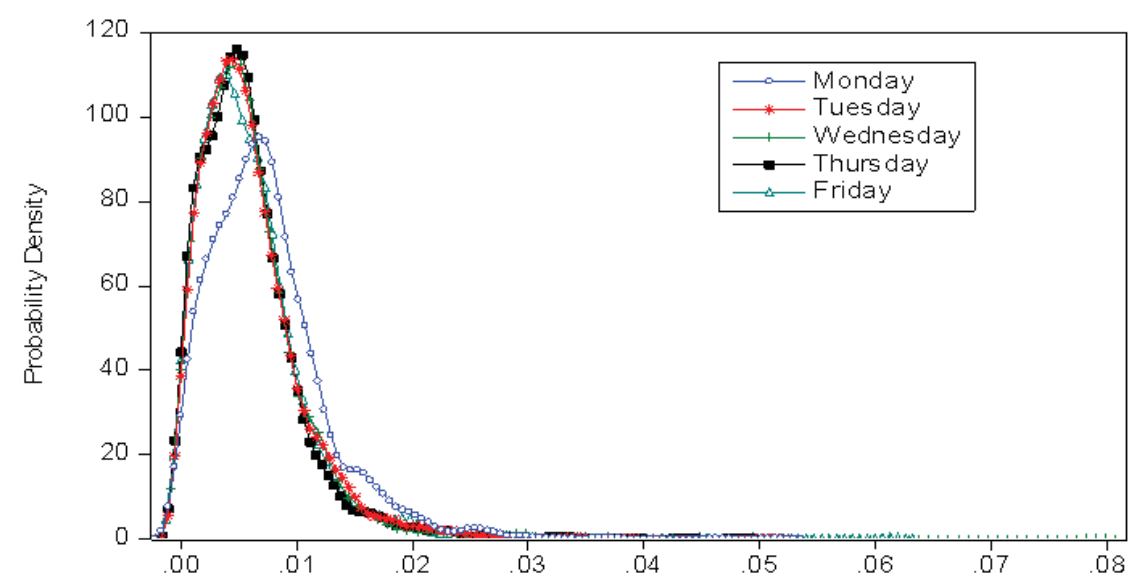

Fig. 9. Probability distributions of gold volatility from Monday to Friday in New York 


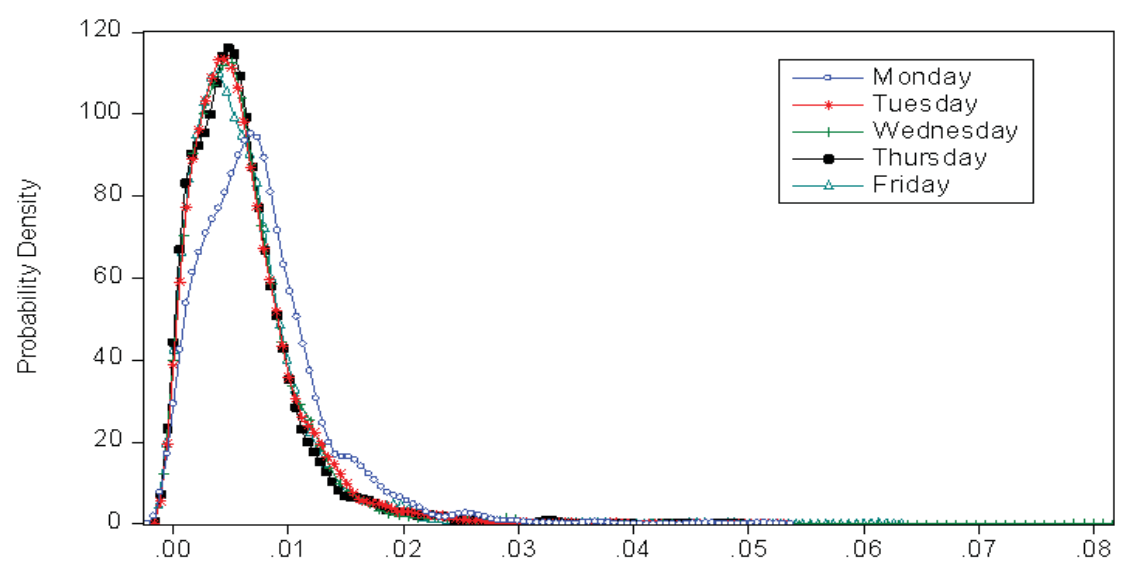

Fig. 10. Probability distributions of gold volatility from Monday to Friday in Tokyo

Figures 8, 9 and 10 show corresponding graphs of the gold volatility distributions from Monday to Friday in London, New York, and Tokyo, respectively. London exhibits higher volatility than New York and Tokyo on all weekdays, implying that London prices reflect most of the economic instability and expectations. Furthermore, the highest and the lowest volatility in London, New York, and Tokyo appear on Monday and Friday, respectively. If volatility is related to trading volume, these results imply a positive relationship between returns and trading volume and a discrepancy among investors beliefs. We will discuss this in the next section.

\section{Conclusions and discussion}

Using probability distribution approach, we found that the weekend effects still exist in the gold market across the London, New York, and Tokyo. However, Monday effects disappear. Instead, Tuesday shows negative and significantly lower returns than other weekdays across the three markets. These results imply that the investors who keep gold over the weekends has the possibility of winning more premium compared to weekdays. The explanation for the negative discounts on Tuesday could be that usually worce news released during the weekends. These bad news influences the investors negatively, leading them to sell on the following day. However, the bad news affecting the weekend is usually the markets in the US, that indirectly influence other markets by one day lagged.

These findings can be evaluated as assistive information in applications like defining the time of purchase/sale by an investor in London, New York, and Tokyo. If an investor buys gold earlier on Friday in London and sell it lately on Tuesday in Tokyo, the possibility of his or her obtaining an above-average premium is strong.

Moreover, although Friday effect still exists in gold, its probability distribution shows a leftward-shifting, meaning that the effect has been starting earlier from
Wednesday and Thursday in London and New York. These findings also indicate that investors have already implemented the buying strategy in advance, that being said, before Friday and make average returns on Friday the highest. The plausible reason could be that holding gold is not costly or risky over the weekend, although a risk aversion to whatever risk remains an explanation. Besides, the online trading or arbitrage has been making the intended transaction quicker and earlier.

We found that London shows the highest returns, followed by New York and Tokyo. New York has the lowest volatility, while London and Tokyo show the similar volatility distributions, implying similar investor risk - return preference behavior between the London and New York gold markets. We attribute this phenomenon to the overlap of the trading time between the two markets. It also implies that arbitrage opportunities between London and New York are trivial and that, instead, Tokyo will be a better market to arbitrage.

The holding period for gold lengthens from Friday to the following Tuesday may also a good reference for hedgers or traders who intend to reduce the uncertainty surrounding the return on gold transactions, due to traders may wish to time their order flows so as to avoid the release of information that has been shown to affect prices.

In addition, the mean returns of gold vary substantially with the day of the week, with prices reacting to specific scheduled announcements or settlement effects in the U.S. For the gold market, the lowest volatility appears on Thursday in New York, while the highest volatility appears on Monday in Tokyo, showing that the trading volume is larger on Monday in Tokyo, and a lesser trading on Thursday in New York. These results are valuable for those frequently trading in gold markets or long-term market participants who make trading decisions based on the release of potentially price-sensitive information or announcements. 


\section{References}

1. Arsad, Z., A.J. Coutts. (1996). The weekend effect, good news, bad news and the Financial Times Industrial Ordinary Shares Index, Applied Economics Letters, 3, pp. 797-801.

2. Aydoğan, K., B.G. Geoffrey. (2003). Calendar anomalies in the Turkish foreign exchange markets, Applied Financial Economics, 13, pp. 353-361.

3. Ball, C., W. Torous, A. Tschoegl. (1982). Gold and the weekend effect, Journal of Futures Markets, 2 (2), pp. $175-182$.

4. Chen, C., C. Lee, A. Wang. (2002). A note on stock market seasonality: the impact of stock price volatility on the application of dummy variable regression model, Quarterly Review of Economics and Finance, 42 (1), pp. $155-162$.

5. Coats, W., Jr. (1981). The weekend eurodollar game, Journal of Finance, 34 (3), pp.649-659.

6. Corhay, A.C., A.M. Fatemi, A.T. Rad. (1995). On the persistence of a day of the week effect in foreign exchange markets, Managerial Finance, 21, pp. 32-41.

7. Coutts, J.A. (1999). Friday the thirteenth and the Financial Times Industrial Ordinary Shares Index 1935-94, Applied Economics Letters, 6, pp. 35-37.

8. Coutts, J.A., M.A. Sheikh. (2000). The January effect and monthly seasonality in the All Gold Index on the Johannesburg Stock Exchange 1987-1997, Applied Economics Letters, 7, pp. 489-492.

9. Cross, F. (1973). The behavior of stock prices on Fridays and Mondays, Financial Analysts Journal, 29 (6), pp. 67-69.

10. Dyl, E., S. Martin, Jr. (1985). Weekend effects on stock returns: a comment, Journal of Finance, 40 (1), pp. 347-349.

11. Fama, E. (1991). Efficient capital markets: II, Journal of Finance, 46 (5), pp. 1575-1617.

12. Flannery, M.A. Protopapadakis. (1988). From T-bills to common stocks: investigating the generality of intra-week return seasonality, Journal of Finance, 43 (2), pp. 431-450.

13. French, K. (1980). Stock returns and the weekend effect, Journal of Financial Economics, 8 (1), pp. 55-69.

14. Gibbons, M.P. Hess. (1981). Day of the week effects and asset returns, Journal of Business, 54 (4), pp. 579-596.

15. Griffiths, M.D. Winters. (1995). Day-of-the-week effects in federal funds rates: further empirical findings, Journal of Banking and Finance, 19 (7), pp. 1265-1284.

16. Johnston, E., W. Kracaw, J. McConnell. (1991). Day-of-the-week effects in financial futures: an analysis of GNMA, T-bond, T-note, and T-bill contracts, Journal of Financial and Quantitative Analysis, 26 (1), pp. 23-44.

17. Jordan, S., B. Jordan. (1991). Seasonality in daily bond returns, Journal of Financial and Quantitative Analysis, 26 (2), pp. 269-285.

18. Kallunki, J.-P., T. Martikaninen. (1997). Trading patterns of small and large traders: implications for the weekend effect in Finland, Applied Economics Letters, 4, pp. 595-597.

19. Lakonishok, J., M. Levi. (1982). Weekend effects on stock returns: a note, Journal of Finance, 37 (3), pp. 883-889.

20. Lauterbach, B., U. Meyer. (1992). Calendar anomalies: some perspectives from the behavior of the Israeli stock market, Applied Financial Economics, 2, pp. 57-60.

21. Ma, C. (1986). A further investigation of the day-of-the-week effect in the gold market, Journal of Futures Markets, 6 (3), pp. 409-420.

22. Ma, C., P. Goebel. (1991). On the seasonalities of mortgage-backed security prices, Journal of Real Estate Research, 6 (1), pp. 19-38.

23. Maberly, E. (1995). Eureka! Eureka! Discovery of the Monday effect belongs to the ancient scribes, Financial Analysts Journal, 51 (5), pp. 10-11.

24. McFarland, J., R. Pettit, S. Sung. (1982). The distribution of foreign exchange prices changes: trading day effects and risks measurement, Journal of Finance, 37 (3), pp. 693-715.

25. Redman, A., H. Manakyan, K. Llano (1997). Real estate investment trusts and calendar anomalies, Journal of Real Estate Research, 14 (1), pp. 19-28.

26. Singleton, J. C., J. Wingender. (1994). The nonparallel weekend effect in the stock and bond markets, Journal of Financial Research, 17 (4), pp. 531-538.

27. Sullivan, R., A. Timmermann, H. White. (2001). Dangers of data mining: the case of calendar effects in stock returns, Journal of Econometrics, 105 (1), pp. 249-286.

28. Thatcher, J., L. Blenman. (2001). Synthetic trades and calendar day patterns: the case of the dollar/sterling markets, Financial Review, 36 (2), pp. 177-200.

29. Yu, H.C., M.-C. Huang. (2004). Statistical Properties of Volatility in Fractal Dimension And Probability Distribution Among Six Stock Markets - USA, Japan, Taiwan, South Korea, Singapore, and Hong Kong, Applied Financial Economics, 14 (15), pp. 1087-1095.

30. Yu, H.C., I. Chiou, J.W. James. (2008). Does the weekday effect of the yen/dollar spot rates exist in Tokyo, London, and New York? An analysis of panel probability, Applied Economics, 40 (20), pp. 2631-2643. 